Journal An-Nafs: Kajian Penelitian Psikologi

http://ejournal.iai-tribakti.ac.id/index.php/psikologi e-ISSN: 2549-6166

p-ISSN: 2528-0600

\title{
HUBUNGAN ANTARA DUKUNGAN SOSIAL DARI DOSEN DENGAN MOTIVASI MENYELESAIKAN SKRIPSI PADA MAHASISWA
}

\author{
Didik Widiantoro, Sigit Nugroho \& Yanwar Arief \\ didikwidiantoro@psy.uir.ac.id \\ Universitas Islam Riau \\ https://doi.org/10.33367/psi.v4i1.649
}

\begin{abstract}
Abstrak
Adapun tujuan dilakukannya penelitian ini untuk mengetahui hubungan antara dukungan sosial dosen dengan motivasi dalam penyelesaian skripsi pada mahasiswa. Subjek dalam penelitian ini adalah 100 mahasiswa perguruan tinggi. Teknik pengambikan data dengan menggunakan purposive sampling. Data penelitian dikumpulkan dengan menggunakan (1) Skala dukungan sosial dosen, dan (2) motivasi dalam penyelesaian skripsi. Selanjutnya Analisis data menggunakan analisis korelasi Pearson Product Moment, dengan program komputer SPSS 18 for windows. Hasil penelitian, menunjukkan ada hubungan yang signifikan antara dukungan sosial dosen dengan motivasi dalam penyelesaian skripsi mahasiswa. Semakin tinggi dukungan sosial dosen, semakin tinggi motivasi dalam menyelesaikan tesis mahasiswa dan semakin rendah dukungan sosial dosen, semakin rendah motivasi dalam penyelesaian skripsi pada mahasiswa. Ditunjukkan dengan nilai $r=0,398$ dan $p=0,00(p<0,01)$.
\end{abstract}

Kata kunci : Dukungan Sosial Dosen, Motivasi penyelesaian skripsi, dan mahasiswa. 
Didik Widiantoro, Dkk | Hubungan Antara Dukungan Sosial

\begin{abstract}
The purpose of this research was to determine the correlation between lecturer's social support with motivation in thesis completion of college students. The subjects in this study were 100 college students. Sampling technique used was purposive sampling technique. The research data were collected using (1) The scale of lecturer's social support, and (2) motivation in thesis completion. Data analysis was performed with the technique of correlation analysis of Pearson Product Moment with the help of a computer program SPSS 18 for windows. The results of the research showed that there was significant correlation between lecturer's social supports with motivation in thesis completion of college students. The higher lecturer's social support, the higher motivation in thesis completion of college students and the lower lecturer's social support, the lower motivation in thesis completion of college students. Indicated by the value of $r=0,398$ and $p=0,00(p<0.01)$.
\end{abstract}

Keywords : Lecturers Social Support, Motivation in thesis completion, and college students.

\title{
Pendahuluan
}

Seorang ahli filsafat bernama Thomas Huxley mengatakan bahwa hasil yang paling penting dari semua pendidikan adalah kemampuan individu untuk membuat dirinya mampu melakukan sesuatu yang harus dilakukan disaat ketika sesuatu itu memang harus dilakukan Salah satu fenomena yang membuktikan kebenaran Thomas Huxley adalah kenyataan bahwa banyak di perguruan tinggi mahasiswa-mahasiswa cenderung untuk mengalami hambatan dalam menyelesaikan studi ketika mereka memasuki masa penulisan skripsi (Brown, dalam Arifin 2004).

Skripsi merupakan karya ilmiah yang menjadi tugas akhir mahasiswa sarjana berdasarkan penelitian yang sistematis dan seksama yang berkonsultasi pada dua orang dosen pembimbing. Suatu Universitas yang memiliki program sarjana umumnya menurut mahasiswa mampu menyelesaikan skripsi sebagai mendapat gelar (Faiza, 2008). Skripsi juga diartikan sebagai salah satu syarat wajib yang harus diambil oleh mahasiswa agar mendapatkan ijazah strata satu. 
Kecenderungan mahasiswa psikologi untuk membuang banyak waktu dalam mengerjakan skripsi juga ditunjukan oleh kenyataan banyaknya mahasiswa yang tidak segera mendaftarkan judul skripsi walaupun mahasiswa-mahasiswa telah menyelesaikan mata kuliah yang menjadi syarat untuk mengajukan judul skripsi (Faiza, 2008)

Berdasarkan hasil pengamatan dan wawancara yang dilakukan Nova (2010) pada 15 sampai 20 orang mahasiswa yang sedang mengerjakan tugas akhir (skripsi), mereka mengatakan bahwa dalam mengerjakan tugas akhir (skripsi) sering mengalami kendala yang datang dari intrinsik maupun ektrinsik, ada pun kendala-kendala tersebut merupakan mahasiswa yang kurang mau membaca literatur, mahasiswa yang tidak memiliki niat untuk menulisa, mahasiswa yang tidak memeiliki minat akademik yang baik dan mahasiswa yang tidak memiliki minat untuk meneliti. Kendala lain adalah ketakutan menghadapi dosen pembimbing, sulitnya mancari refrence atau literatur baik dari buku maupun dari warung internet dan otak buntu ketika mengerjakan skipsi. Alasan semua tersebut juga didukung oleh beberapa data yang diperoleh oleh peneliti mengenai banyaknya keluhan seorang mahasiswa dalam penyelesaian tugas akhir mereka. Salah satu alasan yang diperoleh adalah sulitnya menemui dosen pembimbing. Hal tersebut mempengaruhi keinginan minat mahasiswa dalam menyelesaikan tugas akhir dalam waktu yang singkat.

Kecenderungan mahasiswa tidak kunjung menyelesaikan skripsi menurut penelitian yang dilakukan oleh Utama (2008), disebabkan oleh beberapa faktor-faktor psikologis yang mempengaruhi proses penulisan skripsi. Faktor-faktor psikologi tersebut dipengaruhi oleh dua aspek : 1) Aspek dalam diri yaitu hal-hal yang menjadi hambatan dan dorongan pribadi. 2) Aspek luar diri yaitu aktivitas mahasiswa, tema skripsi dan dosen pembimbing skripsi. Masalah-masalah tersebut dipandang sebagai suatu ancaman yang dapat menyebabkan situasi yang menekan, mengancam dan tidak menyenangkan bagi mahasiswa, 
Didik Widiantoro, Dkk | Hubungan Antara Dukungan Sosial

dan akhirnya mengalami kecemasan dan kekhawatiran terhdap sesuatu yang mungkin terjadi kegagalan.

Lingkungan sosial utama mahasiswa di rumah adalah orangtua. Lingkungan sosial di kampus adalah dosen dan temanteman. Dosen dan teman-teman memiliki pengaruh yan g besar terhadap konsep diri dan motivasi mahasiswa dalam perkuliahan. Menurut Walgito (dalam Faiza, 2008) adalah hubungan antara siswa dan guru haruslah bersifat timbal balik, yakni saling menerima dan mempercayai sehingga tujuan yang diinginkan dari proses belajar mengajar dapat tercapai. Seperti yang dikatakan oleh (Coopersmith dan Fieldman (dalam Faiza, 2008) bahwa pada dasarnya individu tidak mau menerima informasi dan menerima bimbingan dari orang-orang dewasa yang tidak dipercayainya,yaitu orang-orang dewasa yang menolak mereka, sebaliknya mereka akan menerima orang dewasa yang tidak menolak mereka dan mempercayai mereka.

Dengan kata lain jika mahasiswa menganggap bahwa dosen tidak mempercayainya, menolak atau tidak mendukung apapun yang dilakukannya maka mahasiswa juga akan menolak segala informasi, bimbingan, dukungan dan saran yang diberikan oleh dosen. Jika sudah demikian maka menurut Gordon (1986) individu akan merasa tidak dipercayai kemudian akan terjadi salah paham, merasa diremehkan, dikritik dan dinilai tidak objektif.

Kesalahpahaman dan perasaan diremehkan, dikritik dan dinilai tidak objektif yang dirasakan oleh mahasiswa tentu akan sangat mempengaruhi jalan proses perkuliahan dan proses pengerjaan skripsi mahasiswa yakni bagaimana mahasiswa memandang dirinya, menilai dirinya, apakah benar yanng dikatakan orang lain tentang dirinya, dan jika ia menghargai dengan pendapat orang lain yang buruk maka halini akan membuat jiwa dan pola pikir mahasiswa tersebut menjadi negatif.

Gordon (1986) juga mengatakan ternyata banyak tenaga pengajar yang tidak mengetahui tentang apa yang harus dilakukan bila, mahasiswa datang kepadanya dengan menyampaikan 
keluhan-keluhan masalah. Banyaknya masalah yang dihadapi mahasiswa tidak dapat diabaikan begitu saja karena proses perkulihan dan penyelesaian skripsi tidak dapat berjalan lancar apabila mahasiswa mengalami hambatan-hambatan seperti, tekanan batin, merasa tidak aman dan tidak menguasai materi. Maka pada kondisi seperti ini, dukungan sosial dan perhatian dosen akan melahirkan motivasi diri mahasiswa terhadap masalah yang dihadapinya.

Berdasarkan penjelasan diatas maka peneliti melihat yang menjadi salah satu faktor yang dapat mempengaruhi motivasi menyelesaikan skripsi mahasiswa adalah dukungan sosial dari dosen. Pengertian dukungan sosial menurut House (dalam Rohman, 2008) merupakan suatu bentuk komunikasi antara individu yang terlibat dukungan emosional berupa pemberian empati dan perhatian, dukungan peralatan (instrumental) berupa bantuan dalam mempersiapkan alat-alat yang dibutuhkan dan bantuan dalam melaksankan tugas serta memberika peluang waktu, dukungan informasi berupa pemberian nasehat, saran dan pengarahan serta dukungan penilainan terhadap hasil kerja, prestasi yang dicapai,memberikan pengarahan dan kritik yang membangun.

Berdasarkan fenomena yang telah peneliti kemukakan diatas, maka peneliti menyimpulkan bahwa motivasi menyelesaikan skripsi mahasiswa dapat dipengaruhi oleh dukungan sosial dari dosen. Hal ini menarik minat peneliti untuk mencoba mengangkatnya dalam sebuah penelitian dengan judul : "Hubungan antara dukungan sosial dari dosen dengan motivasi menyelesaikan skiprsi Pada Mahasiswa Fakultas di Universitas Islam Riau" .

\section{Dukungan Sosial dari Dosen}

Menurut Saronson (2005) bahwa dukungan sosial adalah sebuah perhatian atau kepercayaan dalam bentuk dorongan atau semangat yang diberikan kepada orang lain yang dimaksudkan untuk memberi bantuan. Johnson and Johnson memberikan 
Didik Widiantoro, Dkk | Hubungan Antara Dukungan Sosial

pendapat dukungan sosial adalah memberikan sebuah bantuan atau pertolongan berupa emosi, materi dan informasi yang memiliki peran sebagai peningkatan kesejahteraan manusia. Pertolongan tersebut diberikan dengan target tujuan pada individu yang memiliki masalah terkait perhatian dan dukungan.

Pada umumnya dukungan sosisal merupakan gambaran dari peranan dan pengaruh yang dapat ditumbulkan orang lain. Menurut Levit (1993) dukungan sosial muncul bersumber dari keluarga. Mereka merupakan orang terdekat yang saling memberikan kekuatan dan perhatian. Perhatian dan dukungan tersebut selalu datang ketika dibutuhkan. Dukungan sosial merupakan informasi dari orang lain bahwa ia cintai dan diperhaikan, dimiliki harga diri dan dihargai, serta merupakan bagian dari jaringan komunikasi dan kewajiban bersama. Jadi dukungan sosial utama bersumber dari keluarga terdekat.

\section{Pentingnya Dukungan Sosial}

Memberikan dukungan sosial dapat sangat berarti bagi individu lain untuk membangkitkan rasa percaya diri dan menghindarkan individu dari rasa pesimis dan rasa tidak berarti. Namun, dukungan sosial yang terlalu berlebihan dapat membuat individu menjadi besar kepala dan membuat dukungan sosial tersebut sebagai pembenaran terhadap suatu perbuatan yang salah (Suhita, 2005). Dengan kata lain, seseorang akan menjadi kuat dalam melalukan sesuatu dengan diperkuat oleh dukungan sosial yang diperolehnya dari lingkungan keluarga dan sekitarnya.

\section{Aspek-Aspek Dukungan Sosial}

Hause (dalam Rohman, 1997) menjelaskan dukungan sosial menjadi 4 bagian yaitu:

a. Dukungan emosional merupakan dukungan atau dorongan yang diberikan dalam bentuk rasa percaya

b. Dukungan peralatan merupakan dukungan yang diberikan dalam bentuk ketersediaan benda 
Didik Widiantoro, Dkk | Hubungan Antara Dukungan Sosial

c. Dukungan informasi merupakan dukungan yang diberikan dalam bentuk keterangan atau nasihat-nasihat untuk membuat individu menjadi lebih baik

d. Dukungan penilaian merupakan dukungan yang diberikan dalam bentuk penghargaan atas sesuatu yang telah diperbuat

\section{Teori-teori Motivasi}

Pada dasarnya manusia di dalam kehidupan selalu memiliki tingkat-tingkat kebutuhan yang belum terpenuhi dan untuk memenuhi kebutuhan-kebutuhan tersebut maka manusia akan terus berusaha.

Manusia memiliki motivasi berdasarkan tingkat kebutuhan, yaitu motivasi akan kebutuhan biologis seperti makan, udara, dll; dan motivasi sekunder. Namun manusia juga memiliki motivasi akan emosi marah, sedih, dll; serta motivasi berperilaku sesuai nilai dan minat.

Sebagian ahli psikologi Stagner 1961 (dalam Hasan, 1986) membagi manusia kepada tiga bagian:

1. Motivasi-motivasi biologis yaitu yang menyatakan bentukbentuk primer atau dasar yang menggerakkan kekuatan seseorang yang timbul sebagai akibat dari keperluankeperluan organik tertentu, seperti: lapar, dahaga, kekurangan udara dan letih, evolusi menjauhi rasa sakit. Keperluan-keperluan ini mencerminkan suasana-suasana yang mendorong seseorang untuk mengerjakan suatu tingkah laku.

2. Emosi seperti: rasa takut, marah, gembira, cinta, benci, jijik. Emosi seperti ini menunjukkan adanya keadaan-keadaan dalam yang mendorong seseorang untuk mengerjakan tingkah laku tertentu.

3. Nilai-nilai dan minat. Nilai-nilai dan minat seseorang bekerja sebagai motivasi-motivasi yang mendorong seseorang membuat tingkah laku seseuai dengan nilai-nilai dan minat yang dimilikinya (Hasan, 1986). 
Didik Widiantoro, Dkk | Hubungan Antara Dukungan Sosial

\section{Pengertian Skripsi}

Menurut Widharyanto (dalam Sudianto, 2006) skripsi merupakan suatu penelitian karya ilmiah yang dibuat oleh mahasiswa pada tingkat perguruan tinggi sebagai syarat mendapatkan gelar kesarjanaan.

Skripsi adalah karya ilmiah yang dibuat mahasiswa strata satu dengan membahas topik masalah tertentu berdasarkan kajian pustaka. Dalam pengerjaan tugas akhir atau skripsi mahasiswa didampingi oleh dua pembimbing yang merupakan bagian dari perguruan tinggi tempat mahasiswa tersebut kuliah.

Terdapat beberapa jenis skripsi, antara lain: (1) Skripsi berdasarkan hasil kajian pustaka, (2) Skripsi yang berdasarkan hasil penelitian lapangan dan, (3) Skripsi yang berdasarkan hasil pengembangan.

Jadi dapat disimpulkan bahwa skripsi adalah suatu karangan ilmiah yang wajib dibuat oleh seorang mahasiswa sebagai syarat untuk menyelesaikan studi program S1 yang bertujuan untuk mendapatkan gelar sarjana.

\section{Pengertian Motivasi Menyelesaikan Skripsi}

Berdasarkan apa yang telah disamapikan di atas bahwa dapat disimpulkan motivasi menyelesaikan skripsi adalah dorongan, semangat, kegigihan, keyakinan, keseriusan, dan memiliki target dalam menyelesaikan suatu karangan ilmiah dalam hal pembuatan skripsi yang wajib dibuat oleh seorang mahasiswa sebagai syarat untuk menyelesaikan studi program S1 yang bertujuan untuk mendapatkan gelar sarjana.

\section{Metode Penelitian}

\section{Subjek}

Subjek dari penelitian adalah mahasiswa dan mahasiswi Fakultas Psikologi Universitas Islam Riau yang telah mengajukan judul skripsi atau sedang melakukan penelitian/skripsi. 
Didik Widiantoro, Dkk | Hubungan Antara Dukungan Sosial

\section{Teknik Sampling}

Teknik pengambilan sampel yang digunakan dengan menggunakan Puposive Sampling. Pengambilan Purposive sampling adalah teknik penentuan sampel data dengan karakteristik tertentu (Sugiono, 2010). Jadi dalam penelitian ini, mahasiswa yang telah mengajukan judul skripsi dapat menjadi subjek penelitian karena telah melengkapi syarat tertentu.

\section{Metode Pengumpulan Data}

Metode pengumpulan data adalah cara untuk mengumpulkan data yang akan dibutuhkan untuk penelitian, maka data tersebut dikumpulkan menggunakan metode skala, dengan tujuan mencari dukungan sosial dan motivasi menyelesaikan skripsi.

Skala penelitian ini disusun berdasarkan modifikasi dari model skala Likert terdapat aitem-aitem yang berupa pernyataanpernyataan yang bersifat Favorabel, yaitu pernyataan-penyataan yang bersifat mendukung, dan pernyataan-pernyataan yang bersifat Unfavorabel, yaitu pernyataan yang bersifat tidak mendukung. Subjek diminta untuk menyatakan kesetujuan dan ketidaksetujuannya terhadap isi pernyataan dalam empat jawaban kemungkinan, yaitu Sangat Sesuai (SS), Sesuai (S), Tidak Sesuai (TS), dan Sangat Tidak Sesuai (STS) (Azwar, 2005).

\section{Metode Analisi Data}

Setelah melakukan uji prasyarat analisis, kemudian pengujian Hipotesis menggunakan analisis korelasi Product Moment. Semua perhitungan analisis dilakukan dengan menggunakan perangkat lunak Statistic Program For Social Science seri 18.00 for windows.

\section{Hasil Dan Pembahasan}

Hasil analisis statistik terlihat bahwa hubungan kepercayaan diri dengan penyesuaian sosial diperoleh korelasi sebesar 0.398 dengan $\mathrm{p}=0.000(\mathrm{p}<0.01)$, artinya ada hubungan 
Didik Widiantoro, Dkk | Hubungan Antara Dukungan Sosial

positif yang sangat signifikan antara dukungan sosial dengan motivasi menyelesaikan skripsi pada mahasiswa, dengan demikian hipotesis diterima.

\section{Pembahasan}

Tujuan penelitian ini untuk melihat hubungan antara kepercayaan diri dengan kewirausahaan mahasiswa. Berdasarkan analisis yang dilakukan dengan bantuan program SPSS 17,0 for Windows telah didapatkan hasil bahwa memang ada hubungan diantara keduanya dan hipotesis yang telah diajukan oleh peneliti dapat diterima.

Hal ini menunjukan semakin tinggi Dukungan Sosial dari Dosen, Motivasi Menyelesaikan Skripsi mahasiswa semakin tinggi. Namun sebaliknya semakin rendah dukungan Sosial, maka Motivasi Menyelesaikan Skripsi mahasiswa juga akan semakin rendah. Kita dapat mengetahui tingginya hubungan tersebut dengan koefisien korelasi (r) sebesar 0,398 dan $\mathrm{p}=0,00(\mathrm{p}<0,01)$.

Penelitian ini menunjukkan bahwa tingginya motivasi menyelesaikan skripsi yang dimiliki mahasiswa, dipengaruhi oleh tingginya dukungan sosial dari dosen. Deskriptif data penelitian dari 100 subjek menunjukkan, untuk Dukungan Sosial kriteria sangat tinggi $6 \%$ subjek, untuk kriteria tinggi terdapat $30 \%$ subjek, sementara untuk kriteria sedang terdapat 37\%, untuk kriteria rendah terdapat $23 \%$ subjek dan sangat rendah tidak terdapat 4\% subjek. Sementara untuk Motivasi, bahwa $5 \%$ subjek berada pada kategori sangat tinggi, $29 \%$ terdapat pada kategori tinggi, $35 \%$ terdapat pada kategori sedang dan $29 \%$ berada dalam kategori rendah, sementara pada kategori sangat rendah tidak 5\% subjek.

Katc dan Kahn (2000) menyampaikan, dukungan sosial adalah sikap positif, kepercayaan, serta perhatian dari orang lain yakni orang yang memiliki arti dalam kehidupan orang tersebut. Sehingga individu yang mendapat dukungan sosial maka kehidupan dilingkunganya akan lebih memiliki makna. 
Motivasi adalah keadaan psikologis yang merangsang dan memberi arah terhadap aktifitas manusia atau kekuatan yang mendorong aktifitas seseorang. Motivasi seseorang itulah yang membimbingnya kearah tujuan-tujuan, begitulah tujuan-tujuan dan aktifitas-aktifitas seseorang berkaitan dengan motivasinya. Sedangkan tujuan adalah apa yang terdapat pada lingkungan yang mengelili seseorang yang pencapaiannya membawa kepada pemuasan motivasi tertentu (Hasan, 1986).

Motivasi merupakan kondisi psikologis yang memberikan arahan terhadap kegiatan manusia atau kekuatan yang mendorong kegaitan manusia.

Motivasi Ekstrinsik merupakan suatu kegiatan yang bermaksud untuk mendapatkan dari yang lain. Sering sekali dibilinag sebagai insentif dari luar yang berupa penghargaan dan hukuman. Sedangkan motivasi instrinsik merupakan kegiatan yang bertujuan untuk diri sendiri (Santrock, 2009).

Kendala dalam penelitian ini adalah proses pengambilan data yang memakan waktu cukup lama, karena kesibukan mahasiswa tingkat akhir yang susah ditemui dikarenakan tidak ada melaksanakan perkuliahan lagi. Kelemahan lainnya, data yang diperoleh hanya murni dari hasil skoring instrumen penelitian yang sudah diisi oleh subjek penelitian, sehingga peneliti tidak memperoleh gambaran faktor-faktor lain yang mempengaruhi motivasi menyelesaikan skripsi pada mahasiswa.

Dalam teori dukungan sosial (Hause, 1997), salah satu aspek dukungan sosial yaitu dukungan emosional yakni seseorang sangat butuh empati. Apabila individu membutuhkan empati. Bila seseorang dapat menghargai, mempercayai, dan mengerti dirinya lebih baik, ia akan menjadi terbuka terhadap aspek-aspek baru dari pengalaman hidupnya. Dari aspek dukungan emosional ini mahasiswa yang mendapatkan dukungan social yang lebih dari dosen akan memiliki dorongan yang kuat untuk menyelesaikan kuliahnya khususnya menyelesaikan skripsi. Dorongan yang kuat merupakan salah satu yang mewakili indikator prilaku dari motivasi menyelesaikan skripsi. Jadi, mahasiswa yang mendapat 
Didik Widiantoro, Dkk | Hubungan Antara Dukungan Sosial

dukungan emosional dari dosen akan memiliki motivasi yang kuat yakni dorongan untuk dapat menyelesaikan skripsi dengan baik dan pada waktu yang tepat.

Diperoleh hubungan positif antara dukungan sosial dengan motivasi menyelesaikan skripsi pada mahasiswa, mahasiswa yang memperoleh dukungan sosial yang tinggi maka tingkat motivasi menyelesaikan skripsi pada mahasiswa akan tinggi. Jika mahasiswa kurang mendapatkan dukungan sosial maka kurang pula memiliki motivasi untuk menyelesaikan skripsinya.

\section{Simpulan}

Adapun kesimpulan dari penelitian ini adalah adanya hubungan yang positif dan signifikan antara dukungan sosial dari dosen dengan motivasi menyelesaikan skripsi mahasiswa. Hal tersebut bahwa semakin tinggi dukungan sosial dari dosen maka semakin tinggi motivasi menyelesaikan skripsi mahasiswa. Dan maka sebaliknya semakin rendah dukungan sosial dari dosen semakin rendah pula motivasi menyelesaikan skripsi mahasiswa.

\section{Saran Praktis}

Berdasarkan pembahasan dan kesimpulan dari penelitian yang telah dilakukan, maka saran yang dapat diajukan adalah sebagai berikut, dari hasil wawancara pada mahasiswa, peneliti mendapatkan masalah tentang kurangnya motivasi menyelesaikan skripsi. Bagi peneliti lain yang akan mengambil tema yang sama hendaknya mempertimbangkan variabel yang lain dalam memilih untuk motivasi menyelesaikan skripsi. 
Didik Widiantoro, Dkk | Hubungan Antara Dukungan Sosial

\section{Daftar Pustaka}

Azwar, S. (2000). Reliabilitas dan validitas. Yogyakarta: Pustaka Belajar.

--------. (2002). Penyusunan skala psikologi. Yogyakarta: Pustaka Belajar.

---------. (2005). Penyusunan skala psikologi. Yogyakarta: Pustaka Belajar.

Azwar, S. (2007). Metode penelitian. Yogyakarta: Pustaka Pelajar.

Faiza, N. (2008). Hubungan antara persaingan lapangan kerja dengan motivasi menyelesaikan skripsi. Skripsi. Universitas Islam Negeri Susqa Pekanbaru: Tidak diterbitkan.

Hadi, S. (2000). Statistis jilid 2. Yogyakarta: Andi.

Hamzah, B. (2006). Teori motivasi \& pengukurannya. Jakarta: Penerbit PT Bumi Aksara

Kartono, K. (1994). Psikologi sosial untuk manajemen perusahaan dan industri. Jakarta: PT Raja Grafindo Persada.

King, A. L. (2010). Psikologi umum : Sebuah pandangan apresiatif. Jakarta : Salemba Humanika.

Nasution, S. (2004). Sosiologi pendidikan. Jakarta: Penerbit PT. Bumi Aksara.

Purwanto, N. (2006). Ilmu pendidikan teoritis dan praktis. Jakarta: Penerbit PT. Remaja Rosdakarya.

Rohman, N. (1997). Hubungan antara dukungan sosial dengan burnout pada perawat putri rumah sakit swasta. Jurnal Psikologi. Vol II, hal 25.

Saronson. (2005). Pengaruh dukungan sosial terhadap prilaku. Jakarta: Penerbit Kencana.

Santrock, W. (2009). Psikologi pendidikan. Jakarta: Penerbit PT. Salemba Humanika.

Siagian, P. S. (2004). Teori motivasi dan aplikasinya. Jakarta: PT. Rineka Cipta.

Sugiyono. (2010). Metode penelitian kuantitatif kualitatif dan $r \& d$. Bandung : Alfabeta.

Sukardi. (2004). Metedologi penelitian pendidikan. Jakarta: Penerbit Bumi Aksara.

Suryabrata, S. (2000). Pengembangan alat ukur psikologis. Yogyakarta: Andi.

Yusuf, S. (2004). Psikologi perkembangan anak dan remaja. Bandung: Penerbit PT. Remaja Rosdakarya. 
Didik Widiantoro, Dkk | Hubungan Antara Dukungan Sosial

Widiantoro, D., Sukarti, S., \& Budiharto, S. (2017). Pelatihan Komunikasi Interpersonal Untuk Meningkatkan Kohesivitas Kelompok Pada Karyawan Hotel X Yogyakarta. JIP: Jurnal Intervensi Psikologi, 9(2), 155-168.

Wirawan, S. S. (2008). Psikologi remaja. Jakarta: PT Raja Grafindo Persada.

Yulianto, F.H., \& Nashori, F. (2006). Kepercayaan diri dan prestasi atlet tae know do. Jurnal Psikologi Dan Ilmu Sosial Budaya UII. 3, 1, 56-60

14 | Journal An-nafs: Vol. 4 No. 1 Juni 2019 